\title{
Polycystic Kidney Disease and the Vasopressin Pathway
}

\author{
Maatje D.A. van Gastel ${ }^{a}$ b Vicente E. Torres ${ }^{a}$ \\ ${ }^{a}$ Division of Nephrology and Hypertension, Department of Internal Medicine, Mayo Clinic, Rochester, MN, USA; \\ ${ }^{b}$ Division of Nephrology, Department of Internal Medicine, University Medical Center Groningen, University of \\ Groningen, Groningen, The Netherlands
}

\author{
Keywords \\ Polycystic kidney disease - Autosomal dominant polycystic \\ kidney disease - Vasopressin - Vasopressin V2-receptor . \\ Hydration · Cyclic AMP · Aquaporin-2
}

\begin{abstract}
Vasopressin, also known as arginine vasopressin or antidiuretic hormone, plays a pivotal role in maintaining body homeostasis. Increased vasopressin concentrations, measured by its surrogate copeptin, have been associated with disease severity as well as disease progression in polycystic kidney disease (PKD), and in experimental studies vasopressin has been shown to directly regulate cyst growth. Blocking vasopressin effects on the kidney via the vasopressin V2-receptor and lower circulating vasopressin concentration are potential treatment opportunities that have been the subject of study in PKD in recent years. Treatment with vasopressin V2-receptor antagonist tolvaptan has been shown to inhibit disease progression in experimental studies, as well as in a large randomized controlled trial involving 1,445 patients with autosomal dominant PKD, lowering total kidney volume growth from 5.5 to $2.8 \%$, and the slope of the reciprocal of the serum creatinine level from -3.81 to -2.61 $\mathrm{mg}$ per $\mathrm{mL}^{-1}$ /year. Alternatively, lowering circulating vasopressin could delay disease progression. Vasopressin is secreted in response to an increased plasma osmolality, which in turn is caused by a low fluid or high osmolar intake. Other lifestyle factors, like smoking, increase vasopressin concentration. Here, we provide a comprehensive review of the
\end{abstract}

\begin{tabular}{ll}
\hline KARGER & $\begin{array}{l}\text { ( } 2017 \text { The Author(s) } \\
\text { Published by S. Karger AG, Basel }\end{array}$ \\
$\begin{array}{l}\text { E-Mail karger@karger.com } \\
\text { www.karger.com/anm }\end{array}$ & $\begin{array}{l}\text { This article is licensed under the Creative Commons Attribution- } \\
\text { NonCommercial-NoDerivatives 4.0 International License (CC BY- } \\
\text { NC-ND) (http://www.karger.com/Services/OpenAccessLicense). } \\
\text { Usage and distribution for commercial purposes as well as any dis- } \\
\text { tribution of modified material requires written permission. }\end{array}$
\end{tabular}

physiology as well as pathophysiology of vasopressin in PKD, the promising effects of tolvaptan treatment, and potential synergistic or additive treatments in combination with tolvaptan. In this study, we also review current evidence regarding the effect of influencing disease progression in PKD by lifestyle changes, especially by fluid intake.

(c) 2017 The Author(s)

Published by S. Karger AG, Basel

\section{Introduction}

In this review, we summarize the current evidence about the pathophysiological relation of vasopressin with the progression of polycystic kidney disease (PKD), and give a comprehensive overview of potential treatment options, by either blocking the effect of vasopressin using the kidney-specific vasopressin V2-receptor antagonist (V2RA) tolvaptan or lowering circulating vasopressin concentration by changing lifestyle and fluid intake in particular. Due to the journal limitation in terms of the number of references allowed, we only included papers and reviews conducted in the last 10 years.

\section{Physiological Actions of Vasopressin}

Arginine vasopressin (AVP) is a hormone pivotal to maintain fluid homeostasis in the body, and is secreted after osmotic as well as hemodynamic stimuli. Vasopressin is 
well known for its antidiuretic effects in the kidney; it also influences the vascular tonus and is involved in the regulation of the endocrine stress response. There are 3 pathways of release for vasopressin. For this review the classical, and most well-known, pathway is relevant. Via this pathway, vasopressin is released directly into the circulation in response to osmotic or hemodynamic stimuli [1].

There are 3 different known receptors for vasopressin that are all part of the subgroup rhodopsin - all G-protein-coupled receptors [1]. Via the V1a-receptor present in many tissues, vasopressin is known to influence hepatic glycogenolysis, platelet aggregation, and vasoconstriction during hypovolemia [1]. The V1b-receptor is found in the adenohypophysis, where it influences adrenocorticotropic hormone secretion, which stimulates the synthesis and secretion of the adrenocortical hormones cortisol, androgens, and aldosterone. The V2-receptor is mainly located in the collecting ducts and the thick ascending limbs of the loops of Henle, and plays a pivotal role in body homeostasis because of its antidiuretic effect [1]. Binding of vasopressin to the V2-receptor in the collecting duct increases water permeability and sodium reabsorption, via the activation of AQP trafficking and the epithelial sodium channel, respectively [2].

In 2006, copeptin was introduced as a biomarker for measuring circulating vasopressin. At that time there was an unmet need to find a biomarker for vasopressin, since vasopressin is a small molecule that is unstable in plasma. Copeptin has been shown to be a reliable surrogate and has been used in many studies in different fields, including cardiovascular, renal disease, and PKD [3].

\section{Pathophysiological Effects of Vasopressin in PKD}

Mutations in either the PKD1 or PKD2 gene cause autosomal-dominant PKD (ADPKD), whereas mutations in the PKHD1 gene cause autosomal recessive $\mathrm{PKD}$ (ARPKD). PKHD1 normally encodes the protein fibrocystin, whereas PKD1 and PKD2 encode polycystin-1 and polycystin-2, respectively [4]. Both disorders are associated with cyst formation in the kidney and are characterized by abnormal excessive fluid secretion, as well as excessive proliferation and apoptosis of the tubular epithelial cells [4].

Vasopressin is increased in patients with $\mathrm{PKD}$, and the concentration of its surrogate copeptin is associated with disease severity when analyzed cross-sectionally [5] and also with disease progression measured longitudinally as kidney function decline and kidney growth $[6,7]$. It has been shown that vasopressin directly regulates cyst growth in rats orthologous to human ARPKD, which phenotypically resembles human ADPKD. After breeding these rats with vasopressin-deficient Brattleboro rats, it was shown that rats lacking vasopressin had lower levels of cyclic adenosine monophosphate (cAMP) and that cystogenesis was inhibited almost completely. Administration of the vasopressin V2-receptor agonist DDAVP recovered the full cystic phenotype in these Brattleboro rats [8].

A urine-concentrating defect is thought to be the cause of the increased vasopressin concentration in PKD. Findings of a decreased urine concentrating capacity in an early phase of ADPKD, before renal impairment occurs, strengthen this hypothesis [9]. When analyzing this urineconcentrating defect in more detail, Bankir et al. [10] observed that this was a urea-selective concentrating defect; patients with PKD had a lower urine/plasma (U/P)-urea ratio, whereas no difference in total U/P osmoles or U/Psodium ratios compared to healthy controls were observed. This defect is thought to originate in the disruption of the medullary architecture by cysts, which reduces the efficiency of countercurrent exchange of urea.

Lowering the vasopressin effect on the kidney could potentially modify the disease course in ADPKD. This either could be accomplished by blocking the effects of vasopressin in the kidney using a vasopressin V2RA like tolvaptan, or could be accomplished by lowering the circulating vasopressin concentration using lifestyle changes such as increased water intake. Recent preclinical studies suggest that additional drugs acting downstream from the vasopressin V2-receptor could enhance and possibly improve the tolerability of vasopressin V2RA and deserve further study. Evidence for these approaches is discussed in the following sections.

\section{Tolvaptan as Treatment for PKD}

The increased vasopressin and cAMP concentration associated with PKD formed the rationale for exploring the effects of vasopressin V2RA. Administration of vasopressin V2RA OPC31260 led to a lowered renal cAMP, inhibited disease development, and either halted progression or caused the regression of established disease in animal models orthologous to the human ARPKD and nephronophthisis (NPH), as well as in mouse models of ADPKD [11].

In the TEMPO 3:4 Trial, a large randomized controlled study including 1,445 patients with ADPKD, tolvaptan slowed the disease progression of ADPKD after 3 years of treatment by a lower total kidney volume (TKV) growth of $2.8 \%$ annually vs. $5.5 \%$ in placebo-treated pa- van Gastel/Torres 


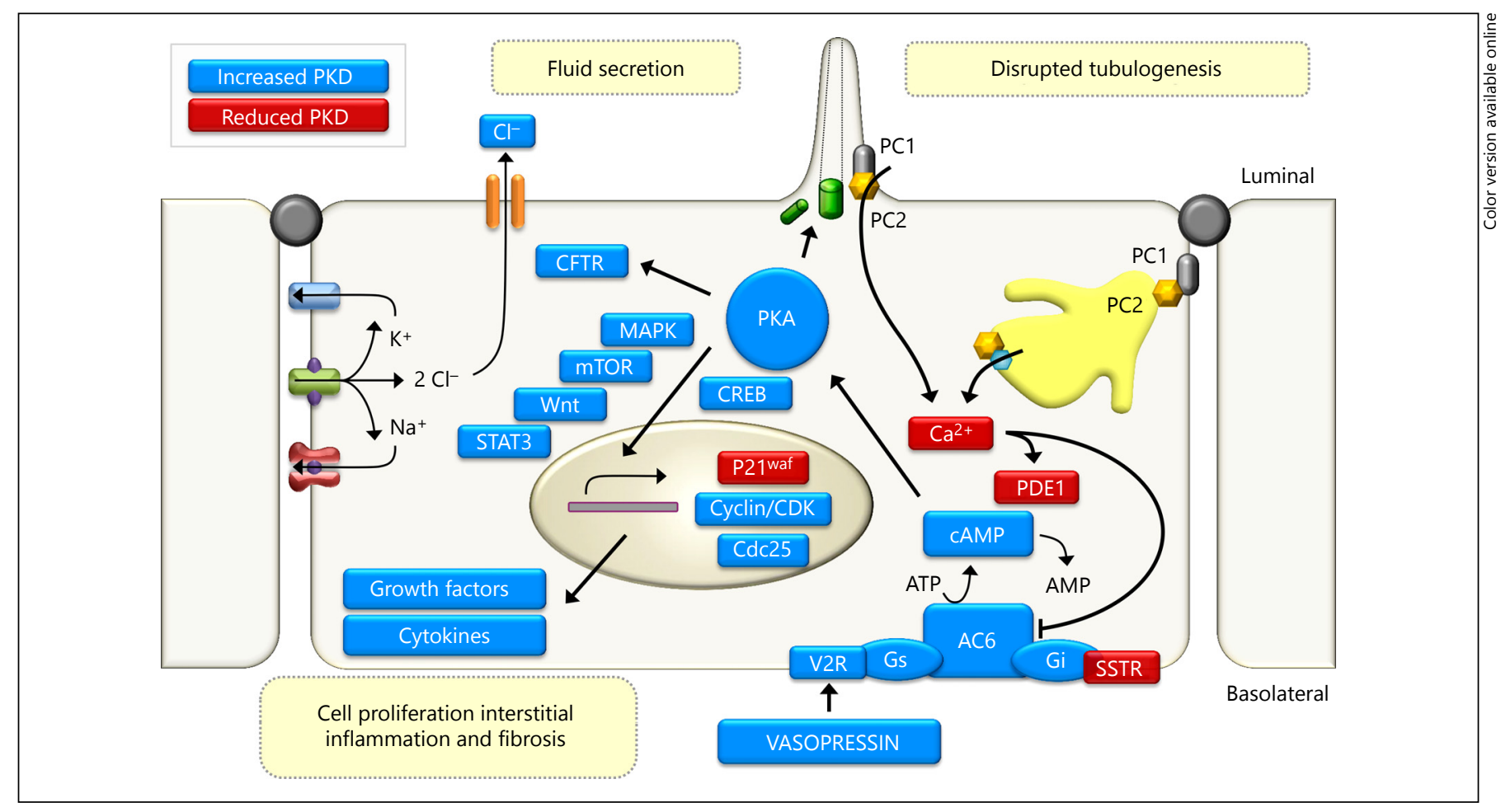

Fig. 1. Intracellular signaling in tubular cells of the collecting duct in ADPKD and the role of vasopressin.

tients $(p<0.001)$, as well as a decreased slope of the reciprocal of the serum creatinine level of -2.61 vs. $-3.81 \mathrm{mg}$ per $\mathrm{mL}^{-1}$ /year in tolvaptan vs. placebo-treated patients, respectively [12]. Patients were eligible if they had an estimated creatinine clearance of $\geq 60 \mathrm{~mL} / \mathrm{min}$. Recent post hoc analyses found similar beneficial effects of tolvaptan in ADPKD across CKD stages 1-3 [13], showed that tolvaptan use lowered albuminuria [14] and monocyte chemotactic protein-1 excretion [15], whereas it increased copeptin concentration [16], and significantly lowered the incidence of kidney pain events from 16.8 to $10.1 \%$ with a risk reduction of $36 \%$ [17]. A higher albuminuria and a higher copeptin concentration at baseline both predicted renal function decline in placebo- as well as tolvaptan-treated patients, and were both associated with a stronger tolvaptan treatment effect $[14,16]$.

\section{Drugs with Effects That Are Potentially Synergistic or Additive to Those of Tolvaptan}

Tolvaptan has been shown to slow down disease progression in ADPKD by antagonizing the vasopressin V2receptor in the kidney (Fig. 1), lowering intracellular cAMP, and inhibiting fluid secretion, and cell proliferation. By interfering with aquaporin-2 (AQP2) trafficking, however, it induces aquaresis and enhances vasopressin release. Combining tolvaptan with treatments that lower cAMP or increase AQP2 in the apical membrane of principal cells could increase its efficacy and reduce the aquaretic side-effects (Fig. 1).

Long-acting somatostatin analogs acting on somatostatin receptors (SSTR) inhibit adenylyl cyclase and slow renal and hepatic cyst expansion in murine and small clinical trials of ADPKD. Hopp et al. [18] found an additive efficacy of tolvaptan and pasireotide (a SSTR-1, $-2,-3$, and -5 analogue) compared to either treatment alone, as well as less aquaresis in the combination therapy compared to tolvaptan alone.

Metformin inhibits complex 1 of the mitochondrial respiratory chain, thus reducing ATP production and increasing AMP [19]. AMP in turn directly inhibits adenylyl cyclase and activates AMPK. The inhibition of adenylyl cyclase [20] and activation of phosphodiesterase (PDE) 4B by AMPK-mediated phosphorylation are found to lower cAMP [21]. Furthermore, via AMPK-mediated phosphorylation of AQP2 metformin enhances its accumulation in the apical membrane and reduces the aquaret- 
Table 1. Different effects of V2R antagonists and enhanced hydration (Bankir et al. [2])

\begin{tabular}{lll}
\hline Outcome & Increased fluid intake & V2R antagonists \\
\hline Patient behavior & Voluntary frequent drinking & Taking a pill \\
\hline Adherence to treatment & Poor (difficult to drink without thirst) & Good (easy) \\
\hline Plasma osmolality & Decreased & Increased \\
\hline Vasopressin secretion and plasma level & Decreased & Increased \\
\hline $\begin{array}{l}\text { Vasopressin effects mediated by other } \\
\text { receptors (V1aR and V1bR)* }\end{array}$ & Reduced & Enhanced \\
\hline Possible side effects & Aversion to water, frequent need to & Thirst, frequent need to \\
urinate, risk of dehydration
\end{tabular}

$\mathrm{V} 1 \mathrm{aR}$, vasopressin V1a receptor; V1bR, vasopressin V1b receptor.

* Note that enhanced V1aR-mediated actions may not be harmful as is usually believed.

ic effect of tolvaptan [22]. Currently, 2 phase- 2 studies are investigating the effect of metformin treatment on disease progression in ADPKD (Clinicaltrial.gov Identifiers: NCT02656017 and NCT02903511).

Statins and tetracycline antibiotics demeclocycline and doxycycline, may also have synergistic effects with tolvaptan. Statins may lower cAMP through the downregulation of $\mathrm{Ga} \alpha_{s}$ protein [23] and induce membrane accumulation of AQP2 via the inhibition of endocytosis [24], thus reducing aquaresis. Demeclocycline decreases adenylate cyclase 5/6 expression and, consequently, cAMP generation [25]. In animal studies, doxycycline significantly decreased renal tubule cell proliferation and inhibited cystic disease progression in a rat model orthologous to human ARPKD [26]. However, the nephrotoxicity of these drugs when used at high doses may limit their potential for the treatment of PKD; for example, doxycycline at a high dose was found to aggravate cyst growth and fibrosis in a mouse model of type $3 \mathrm{NPH}$ [27].

\section{Water Intake}

Lowering vasopressin concentration and slowing down disease progression in PKD by increasing water intake has been a topic of studies for many years. It should be noted that the effects of vasopressin V2RA and enhanced hydration are not identical (Table 1). Promising effects of increased water intake have been found by Nagao et al. [28], who found in rats orthologous to human ARPKD, that high water intake decreased urinary vasopressin excretion by $68.3 \%$, and the renal expression of vasopressin V2-receptors was decreased. High water intake slowed the disease progression in both male and female rats, decreased kidney-body weight ratio to 29.8 and $27.0 \%$, respectively, and reduced the serum urea nitrogen in the male rats from 38.7 to $26.3 \mathrm{mg} / \mathrm{dL}$. Similar results were obtained by Hopp et al. [29] in the same rat model, but not in a Pkd1-mouse model. In these rats, a 4-fold increase in urine output led to reductions in urine vasopressin and renal levels of CAMP, with a marked protective effect on the development of $\mathrm{PKD}$, as reflected by lower kidney weights, plasma urea, and cystic and fibrotic indexes [29].

When studying the effects of increased water intake in human ADPKD, the beneficial effects on disease progression have not yet been confirmed. In a pilot clinical study by Barash et al. [30], 13 ADPKD patients were instructed to increase their water intake for 7 days, resulting in average intake of $3.1 \mathrm{~L} /$ day. This caused a significant urine osmolality decline of $46 \%$ to $270 \mathrm{mOsm} / \mathrm{L}(p=0.04)$, lowering it below plasma osmolality, and thus likely causing a decreased vasopressin concentration (not measured). Higashihara et al. [31] performed a study in 34 patients with ADPKD who received either a high or free water intake during 1 year, leading to mean 24 -h urine volumes of 2.6 vs. $1.4 \mathrm{~L}$ per day $(p<0.001)$. Plasma AVP and copeptin were, as expected, lower in the high water intake group (both $p=0.02$ ). However, non-significant trends toward faster estimated glomerular filtration rate (eGFR) decline $\left(-5.6 \mathrm{~mL} / \mathrm{min} / 1.73 \mathrm{~m}^{2}\right.$ vs. $\left.-1.1, p=0.06\right)$ and TKV growth $(9.68 \%$ /year vs. $5.28, p=0.08)$, rather than a ben- van Gastel/Torres 
eficial effect, were observed in the high water intake group compared to the free water intake group. Finding no beneficial effects of an increased water intake in this study might have been due to shortcomings of the study design. First, the study had only 34 participants, potentially leading to an underpowered statistical analysis. Second, for assessment of the primary end point, historical data were used. Third, participants were not randomized but could enroll in the group they preferred, potentially leading to a selection bias, as is reflected by a significantly higher 24-h urine volume in the high water intake group at baseline. Finally, the high water intake group was instructed to drink $\sim 50 \mathrm{~mL}$ water $/ \mathrm{kg}$ body weight/day $(2.5-3.0 \mathrm{~L}$ of water/day) or more, preferably during the first half of the day, which might not be enough to change the disease course and show a beneficial effect.

These inconclusive results suggest a need for future randomized controlled trials that study the effect of an increased fluid intake on disease progression in CKD and PKD in particular. Currently, there is an ongoing trial studying the effect of increased fluid intake of $1-1.5 \mathrm{~L} /$ day in CKD (Clinicaltrial.gov Identifier: NCT01766687), and another clinical trial in 180 ADPKD patients, of which half will have prescribed fluid intake to reduce urine osmolality to $\leq 270 \mathrm{mOsm} / \mathrm{kg}$ [32].

\section{Dietary Factors}

Besides water intake, other lifestyle factors might influence the disease course of PKD by lowering the vasopressin concentration (Table 2). The recommendations in the KHA-CARI ADPKD guideline for diet and lifestyle management are based on lifestyle modifications that have proven to be effective in the management of early CKD progression, as there is no evidence specific to ADPKD that would alter these recommendations. It includes a moderate protein diet $(0.75-1.0 \mathrm{~g} / \mathrm{kg} /$ day $)$, a restricted dietary sodium intake of $100 \mathrm{mmol} /$ day (i.e., $2.3 \mathrm{~g}$ sodium or $6 \mathrm{~g}$ salt) or less, to drink fluid to satisfy thirst, and to stop smoking [33].

In a large general population cohort, we previously found that a higher copeptin concentration was cross-sectionally associated with lower water intake (measured as 24-h urine volume), higher 24 -h sodium and urea excretion (in steady state markers of sodium and protein intake), a lower 24 -h potassium excretion, higher number of cigarettes smoked, as well as alcohol use and higher number of alcoholic consumptions [34]. Nonlinear relations between copeptin concentration and body mass index, as well as plasma glucose concentration, were observed.

PKD and the Vasopressin Pathway
In the CRISP study involving 241 patients with ADPKD, high urine osmolality (a marker for AVP activity), high urine sodium excretion (a marker for sodium intake), and low serum HDL-cholesterol were associated with the rates of TKV increase and eGFR decline [35]. In a recent post hoc analysis of the HALT-PKD clinical trials, dietary sodium - measured as averaged sodium excretion - showed to be associated with the rate of TKV increase but not with the rate of eGFR decline in ADPKD patients with an eGFR over $60 \mathrm{~mL} / \mathrm{min} / 1.73 \mathrm{~m}^{2}$. In patients with an eGFR 25-60 $\mathrm{mL} / \mathrm{min} / 1.73 \mathrm{~m}^{2}$ averaged sodium excretion was associated with reaching a composite end point of $50 \%$ reduction of eGFR, end-stage renal disease (ESRD) or death, and with a faster rate of eGFR decline [36]. Markers of vasopressin were not studied in the HALT-PKD trials.

Protein intake, both a single meal and chronic high intake, is known to directly increase the circulating vasopressin concentration and simultaneously GFR. It changes the urea handling by the renal tubule, as the fractional excretion of urea is increased following a protein meal, and is thought to participate in glomerular hyperfiltration and kidney hypertrophy [37]. As reviewed in the KHA-CARI guideline, the only study investigating protein intake in ADPKD was a secondary analysis of the MDRD Study analyzing 200 patients with ADPKD, where they found no clear benefit of low protein intake and decline in GFR. Meta-analyses in chronic kidney disease indicate either no effect or a modest benefit of protein-restricted diets [33].

Recently, a very promising pilot study treated $34 \mathrm{ADPKD}$ patients with a low osmolar, water-adjusted diet and observed a lower copeptin concentration on this dietary regime. Patients received a low sodium (1,500 mg/day), low protein (daily protein dietary allowance, $0.8 \mathrm{~g} / \mathrm{kg}$ body weight), and low urea (i.e., avoidance of preservatives, food additives, bulking agents, and chewing gum) diet, combined with individually adjusted water intake, to ensure urine osmolality of $280 \mathrm{mOsm} / \mathrm{kg}$ or lower. After 2 weeks of treatment, patients had significantly lower plasma copeptin levels compared to non-treated patients $(6.2 \pm 3.05$ vs. $5.3 \pm 2.5 \mathrm{pmol} / \mathrm{L}$ respectively; $p=0.02$ ). Total urinary solute decreased only in the intervention group and significantly differed between groups at week $1(p=0.03)$ [38].

\section{Other (Lifestyle) Factors}

Hypothetically, caffeine has a specific deleterious effect in PKD via PDE inhibition, but when analyzing the effects of caffeine intake in a case-control study in 102

Ann Nutr Metab 2017;70(suppl 1):43-50 DOI: $10.1159 / 000463063$ 
Table 2. Studies that suggest an association between lifestyle factors and polycystic kidney disease progression

\begin{tabular}{|c|c|c|c|c|c|}
\hline Study & Model & Lifestyle & Study type & Outcome measure(s) & Main findings \\
\hline $\begin{array}{l}\text { Nagao } \\
\text { et al. [28], } \\
2006\end{array}$ & $\begin{array}{l}\text { Rats } \\
\text { orthologous } \\
\text { to human } \\
\text { ARPKD }\end{array}$ & Water intake & $\begin{array}{l}\text { Interventional } \\
\text { animal study }\end{array}$ & $\begin{array}{l}\text { Urinary AVP } \\
\text { excretion, AVP V2 } \\
\text { receptor expression, } \\
\text { kidney-to-body-weight } \\
\text { (\%), SUN }\end{array}$ & $\begin{array}{l}\text { Urinary AVP excretion decreased by } 68.3 \% \text {, AVP V2 } \\
\text { receptor expression normalized under high water } \\
\text { intake, kidney-to-body-weight decreased } 29.8 \text { and } \\
27.0 \% \text { in male and female rats, respectively, and SUN } \\
\text { decreased from } 38.7 \text { to } 26.3 \mathrm{mg} / \mathrm{dL} \text { in the male rats }\end{array}$ \\
\hline $\begin{array}{l}\text { Hopp } \\
\text { et al. [29], } \\
2015\end{array}$ & $\begin{array}{l}\text { Rats } \\
\text { orthologous } \\
\text { to human } \\
\text { ARPKD and } \\
P k d 1^{\mathrm{RC}} \text {-mice }\end{array}$ & Water intake & $\begin{array}{l}\text { Interventional } \\
\text { animal study }\end{array}$ & $\begin{array}{l}\text { Urine output, plasma } \\
\text { AVP, renal cAMP, } \\
\text { kidney weight, cyst } \\
\text { and fibrosis, plasma } \\
\text { urea and creatinine }\end{array}$ & $\begin{array}{l}\text { Urine output was increased by fourfold and all studied } \\
\text { parameters were lower in rats on a high water intake. } \\
\text { Despite a more than sevenfold increased urine output } \\
\text { in } P k d 1 \text {-mice, no significant differences on any of the } \\
\text { markers were observed }\end{array}$ \\
\hline $\begin{array}{l}\text { Barash } \\
\text { et al. [30], } \\
2010\end{array}$ & $\begin{array}{l}\text { ADPKD } \\
\text { patients }\end{array}$ & Water intake & $\begin{array}{l}\text { Interventional } \\
\text { study }\end{array}$ & $\begin{array}{l}24-\mathrm{H} \text { urine } \\
\text { volume, urine } \\
\text { osmolality }\end{array}$ & $\begin{array}{l}\text { 24-H urine volume increased } 64 \% \text { (to } 3.1 \mathrm{~L} \text { ), urine } \\
\text { osmolality decreased } 46 \% \text { (to } 270 \pm 21 \mathrm{mOsm} / \mathrm{L} \text { ) }\end{array}$ \\
\hline $\begin{array}{l}\text { Higashihara } \\
\text { et al. [31], } \\
2014\end{array}$ & $\begin{array}{l}\text { ADPKD } \\
\text { patients }\end{array}$ & Water intake & $\begin{array}{l}\text { Interventional } \\
\text { study }\end{array}$ & $\begin{array}{l}\text { Plasma AVP } \\
\text { and copeptin, } \\
\text { eGFR decline, } \\
\text { TKV growth }\end{array}$ & $\begin{array}{l}\text { Plasma AVP and copeptin lower in high (HW) vs. low } \\
\text { water }(\mathrm{LW}) \text { intake (both } p=0.02) \text {, whereas no effect on } \\
\text { eGFR decline }\left(\mathrm{mL} / \mathrm{min} / 1.73 \mathrm{~m}^{2}\right) \text {, being }-5.6 \mathrm{HW} \text { vs. }-1.1 \\
\text { LW }(p=0.06) \text { or TKV growth }(9.68 \mathrm{HW} \text { vs. } 5.28 \mathrm{LW} \text {; } \\
p=0.08) \text { were observed }\end{array}$ \\
\hline $\begin{array}{l}\text { Torres } \\
\text { et al. [35], } \\
2011\end{array}$ & $\begin{array}{l}\text { ADPKD } \\
\text { patients }\end{array}$ & $\begin{array}{l}\text { Sodium and } \\
\text { protein intake, } \\
\text { HDL-cholesterol, } \\
\text { BSA, BMI }\end{array}$ & $\begin{array}{l}\text { Multicenter } \\
\text { study, case } \\
\text { series }\end{array}$ & $\begin{array}{l}\text { TKV slope } \\
\text { and eGFR } \\
\text { decline }\end{array}$ & $\begin{array}{l}\text { Urine osmolality (as marker for AVP activity), urine } \\
\text { sodium excretion, and low serum HDL-cholesterol were } \\
\text { associated with TKV and eGFR slopes. Also baseline } \\
\text { BSA, BMI, and estimated protein intake were associated } \\
\text { with TKV increase over time }\end{array}$ \\
\hline $\begin{array}{l}\text { Torres } \\
\text { et al. [36], } \\
2016\end{array}$ & $\begin{array}{l}\text { ADPKD } \\
\text { patients }\end{array}$ & $\begin{array}{l}\text { Sodium intake } \\
\text { (as sodium } \\
\text { excretion) }\end{array}$ & $\begin{array}{l}\text { Post hoc } \\
\text { analysis }\end{array}$ & $\begin{array}{l}\text { TKV growth, eGFR } \\
\text { change and risk to } \\
\text { reach composite } \\
\text { endpoints }\end{array}$ & $\begin{array}{l}\text { Urine sodium excretion was significantly associated with } \\
\text { TKV growth }(p<0.001) \text {, and a non-significant trend for } \\
\text { eGFR decline }(p=0.09) \text {. Average urine sodium excretion } \\
\text { was significantly associated with eGFR decline }(p<0.001) \\
\text { with risk to reach the composite end point of } 50 \% \\
\text { reduction in eGFR, ESRD, or death }\end{array}$ \\
\hline $\begin{array}{l}\text { Amro } \\
\text { et al. [38], } \\
2016\end{array}$ & $\begin{array}{l}\text { ADPKD } \\
\text { patients }\end{array}$ & $\begin{array}{l}\text { Low osmolar } \\
\text { diet and adjusted } \\
\text { water intake }\end{array}$ & $\begin{array}{l}\text { Randomized } \\
\text { controlled trial } \\
\text { (pilot) }\end{array}$ & $\begin{array}{l}\text { Plasma copeptin, urine } \\
\text { osmolality, and total } \\
\text { urinary solute }\end{array}$ & $\begin{array}{l}\text { Mean plasma copeptin levels and urine osmolality } \\
\text { declined from } 6.2 \pm 3.05 \text { to } 5.3 \pm 2.5 \mathrm{pmol} / \mathrm{L}(p=0.02) \text { and } \\
\text { from } 426 \pm 193 \text { to } 258 \pm 117 \mathrm{mOsm} / \mathrm{kg} \text { water }(p=0.01) \text {, } \\
\text { respectively, in the intervention group. Total urinary } \\
\text { solute decreased only in the intervention group and } \\
\text { significantly differed between groups at week } 1(p=0.03)\end{array}$ \\
\hline $\begin{array}{l}\text { Ozkok } \\
\text { et al. [40], } \\
2013\end{array}$ & $\begin{array}{l}\text { ADPKD } \\
\text { patients }\end{array}$ & $\begin{array}{l}\text { Clinical } \\
\text { characteristics } \\
\text { like smoking, } \\
\text { hypertension } \\
\text { and proteinuria }\end{array}$ & $\begin{array}{l}\text { Historical } \\
\text { prospective } \\
\text { study }\end{array}$ & $\begin{array}{l}\text { Decline in } \\
\text { GFR }\end{array}$ & $\begin{array}{l}\text { Rapidly progressing patients had significantly higher } \\
\text { history of smoking ( } 36 \mathrm{vs.} 18 \%, p=0.01 \text { ) and pack-years } \\
\text { of smoking. A Cox regression did not confirm that } \\
\text { smoking predicted progression of CKD in ADPKD } \\
\text { patients ( } p=0.63 \text { ), whereas age, the presence of hepatic } \\
\text { cysts, hypertension, and proteinuria did ( } p=0.01 \text {, } \\
p=0.001, p=0.04 \text { and } p=0.02 \text {, respectively) }\end{array}$ \\
\hline $\begin{array}{l}\text { Orth et al. } \\
{[41], 1998}\end{array}$ & $\begin{array}{l}\text { ADPKD } \\
\text { patients }\end{array}$ & Smoking & $\begin{array}{l}\text { Case-control } \\
\text { study }\end{array}$ & Progression to ESRD & $\begin{array}{l}\text { In smoking men (average pack-years } 16.9 \pm 20.2 \text { ), a } \\
\text { significant dose-dependent increase of the risk to } \\
\text { progress to ESRD compared to controls (average } \\
\text { pack years } 8.2 \pm 14.9 \text { ) was found }(p=0.001 \text { ) }\end{array}$ \\
\hline $\begin{array}{l}\text { Veloso Sousa } \\
\text { et al. [42], } \\
2016\end{array}$ & $\begin{array}{l}P k d 1 \text {-deficient } \\
\text { mice }\end{array}$ & Smoking & $\begin{array}{l}\text { Interventional } \\
\text { animal study }\end{array}$ & $\begin{array}{l}\text { SUN, cystic index, } \\
\text { renal fibrosis and cell } \\
\text { proliferation }\end{array}$ & $\begin{array}{l}\text { In } P k d 1 \text {-mice, smoking increased SUN }(57.2 \pm 32.4 \text { vs. } \\
35.7 \pm 6.0 \mathrm{mg} / \mathrm{dL}, p<0.05) \text {, the cystic index }(17.4 \text { vs. } 4.6 \% \text {; } \\
p<0.05) \text {, renal fibrosis }(1.1 \text { vs. } 0.3 \% ; p<0.0001) \text { and cell } \\
\text { proliferation in cystic epithelia }(2.1 \text { vs. } 1.1 \% ; p<0.05)\end{array}$ \\
\hline
\end{tabular}

ARPKD, autosomal recessive polycystic kidney disease; AVP, arginine vasopressin; SUN, serum urea nitrogen; cAMP, cyclic adenosine monophosphate; ADPKD, autosomal dominant polycystic kidney disease; eGFR, estimated glomerular filtration rate; TKV, total kidney volume; HDL, high-density lipoproteins; BSA, body surface area; BMI, body mass index; ESRD, end-stage renal disease. 
ADPKD patients, no associations were found between coffee intake and eGFR or TKV [39]. However, a majority of these patients $(63 \%)$ had previously been advised to lower coffee consumption, and the mean coffee intake was significantly lower compared to healthy controls (86 \pm 77 vs. $134 \pm 116 \mathrm{mg} /$ day, $p \leq 0.001)$ [39].

Nicotine is known to have an antidiuretic effect and causes an increased vasopressin concentration. A history of smoking and pack-year of cigarettes smoked, were significantly associated with rapid disease progression in ADPKD [40]. In ADPKD patients, smoking also correlated with proteinuria and an increased risk of progression to ESRD [41]. A recent mouse study in $P k d 1$-mice revealed that smoking aggravated the renal phenotype of these mice, thereby supporting the theoretical accelerating effect of smoking on PKD-progression [42].

Vasopressin was associated with obesity, metabolic syndrome, and diabetes mellitus in the Malmö Diet and Cancer Study cardiovascular cohort $(n=2,064)$ [43]. In a separate, small case-control study in subjects with preserved renal function, the presence of ADPKD was associated with components of metabolic syndrome such as hypertension, abdominal obesity, and higher fasting glycemia [44]. Markers of vasopressin concentration were not studied.

\section{Conclusions}

It is important that future studies focus on the relationship between increased fluid consumption and lowering osmolar intake on vasopressin concentration, and most importantly, the progression of PKD. If future research determines that reducing vasopressin concentration leads to slowed disease progression, other lifestyle factors, like smoking and obesity, could be studied because they are associated with increased vasopressin concentrations.

\section{Acknowledgments}

V.E.T. received from Danone Research the reimbursement of travel expenses and registration fee to attend the $\mathrm{H} 4 \mathrm{H}$ Scientific Conference.

\section{Disclosure Statement}

Ms. Maatje D.A. van Gastel has no disclosures or conflicts of interest. Dr. Vicente E. Torres serves in the Steering Committee for the TEMPO 3:4 and TEMPO 4:4 clinical trials and has received research support from Otsuka Pharmaceutical.

\section{References}

1 Bichet DG: Central vasopressin: dendritic and axonal secretion and renal actions. Clin Kidney J 2014;7:242-247.

2 Bankir L, Bouby N, Ritz E: Vasopressin: a novel target for the prevention and retardation of kidney disease? Nat Rev Nephrol 2013; 9:223-239.

3 Morgenthaler NG: Copeptin: a biomarker of cardiovascular and renal function. Congest Heart Fail 2010;16(suppl 1):S37-S44.

4 Torres VE, Harris PC: Mechanisms of disease: autosomal dominant and recessive polycystic kidney diseases. Nat Clin Pract Nephrol 2006; 2:40-55; quiz 55

5 Meijer E, Bakker SJ, van der Jagt EJ, et al: Copeptin, a surrogate marker of vasopressin, is associated with disease severity in autosomal dominant polycystic kidney disease. Clin J Am Soc Nephrol 2011;6:361-368.

6 Boertien WE, Meijer E, Zittema D, et al: Copeptin, a surrogate marker for vasopressin, is associated with kidney function decline in subjects with autosomal dominant polycystic kidney disease. Nephrol Dial Transplant. 2012;27:4131-4137.

7 Boertien WE, Meijer E, Li J, et al: Relationship of copeptin, a surrogate marker for arginine vasopressin, with change in total kidney vol- ume and GFR decline in autosomal dominant polycystic kidney disease: results from the CRISP cohort. Am J Kidney Dis 2013;61:420429.

8 Wang X, Wu Y, Ward CJ, Harris PC, Torres VE: Vasopressin directly regulates cyst growth in polycystic kidney disease. J Am Soc Nephrol 2008;19:102-108.

9 Zittema D, Boertien WE, van Beek AP, et al: Vasopressin, copeptin, and renal concentrating capacity in patients with autosomal dominant polycystic kidney disease without renal impairment. Clin J Am Soc Nephrol 2012;7: 906-913.

10 Bankir L, Bichet DG: Polycystic kidney disease: an early urea-selective urine-concentrating defect in ADPKD. Nat Rev Nephrol 2012; 8:437-439.

11 Torres VE: Vasopressin receptor antagonists, heart failure, and polycystic kidney disease. Annu Rev Med 2015;66:195-210.

12 Torres VE, Chapman AB, Devuyst O, et al: Tolvaptan in patients with autosomal dominant polycystic kidney disease. N Engl J Med 2012;367:2407-2418.

13 Torres VE, Higashihara E, Devuyst O, et al: Effect of tolvaptan in autosomal dominant polycystic kidney disease by CKD stage: re- sults from the TEMPO 3:4 trial. Clin J Am Soc Nephrol 2016;11:803-811.

14 Gansevoort RT, Meijer E, Chapman AB, et al Albuminuria and tolvaptan in autosomaldominant polycystic kidney disease: results of the TEMPO 3:4 trial. Nephrol Dial Transplant 2016;31:1887-1894.

15 Grantham JJ, Chapman AB, Blais J, et al Tolvaptan suppresses monocyte chemotactic protein-1 excretion in autosomal-dominant polycystic kidney disease. Nephrol Dial Transplant 2016;pii:gfw060.

16 Gansevoort RT, van Gastel MD, Chapman $\mathrm{AB}$, et al: Copeptin, a surrogate for vasopressin, predicts disease progression and tolvaptan treatment efficacy in ADPKD. Results of the TEMPO 3:4 trial. J Am Soc Nephrol 2016; 27:34A.

17 Casteleijn NF, Blais JD, Chapman AB, et al: Tolvaptan and kidney pain in patients with autosomal dominant polycystic kidney disease: secondary analysis from a randomized controlled trial. Am J Kidney Dis 2017;69: 210-219.

18 Hopp K, Hommerding CJ, Wang X, et al: Tolvaptan plus pasireotide shows enhanced efficacy in a PKD1 model. J Am Soc Nephrol 2015;26:39-47. 
19 Owen MR, Doran E, Halestrap AP: Evidence that metformin exerts its anti-diabetic effects through inhibition of complex 1 of the mitochondrial respiratory chain. Biochem J 2000; 348(pt 3):607-614.

20 Miller RA, Chu Q, Xie J, Foretz M, Viollet B, Birnbaum MJ: Biguanides suppress hepatic glucagon signalling by decreasing production of cyclic AMP. Nature 2013;494:256-260.

21 Johanns M, Lai YC, Hsu MF, et al: AMPK antagonizes hepatic glucagon-stimulated cyclic AMP signalling via phosphorylation-induced activation of cyclic nucleotide phosphodiesterase 4B. Nat Commun 2016;7: 10856.

22 Efe O, Klein JD, LaRocque LM, Ren H, Sands JM: Metformin improves urine concentration in rodents with nephrogenic diabetes insipidus. JCI Insight 2016;1:pii:e88409.

23 Kou R, Shiroto T, Sartoretto JL, Michel T: Suppression of Gas synthesis by simvastatin treatment of vascular endothelial cells. J Biol Chem 2012;287:2643-2651.

$24 \mathrm{Li} \mathrm{W}$, Zhang Y, Bouley R, et al: Simvastatin enhances aquaporin-2 surface expression and urinary concentration in vasopressin-deficient Brattleboro rats through modulation of Rho GTPase. Am J Physiol Renal Physiol 2011;301:F309-F318.

25 Kortenoeven ML, Sinke AP, Hadrup N, et al: Demeclocycline attenuates hyponatremia by reducing aquaporin-2 expression in the renal inner medulla. Am J Physiol Renal Physiol 2013;305:F1705-F1718.

26 Liu B, Li C, Liu Z, Dai Z, Tao Y: Increasing extracellular matrix collagen level and MMP activity induces cyst development in polycystic kidney disease. BMC Nephrol 2012;13: 109.

27 Osten L, Kubitza M, Gallagher AR, et al: Doxycycline accelerates renal cyst growth and fibrosis in the pcy/pcy mouse model of type 3 nephronophthisis, a form of recessive polycystic kidney disease. Histochem Cell Biol 2009;132:199-210.
28 Nagao S, Nishii K, Katsuyama M, et al: Increased water intake decreases progression of polycystic kidney disease in the PCK rat. J Am Soc Nephrol 2006;17:2220-2227.

29 Hopp K, Wang X, Ye H, Irazabal MV, Harris PC, Torres VE: Effects of hydration in rats and mice with polycystic kidney disease. Am J Physiol Renal Physiol 2015;308:F261-F266.

30 Barash I, Ponda MP, Goldfarb DS, Skolnik EY: A pilot clinical study to evaluate changes in urine osmolality and urine cAMP in response to acute and chronic water loading in autosomal dominant polycystic kidney disease. Clin J Am Soc Nephrol 2010;5:693-697.

31 Higashihara E, Nutahara K, Tanbo M, et al: Does increased water intake prevent disease progression in autosomal dominant polycystic kidney disease? Nephrol Dial Transplant 2014;29:1710-1719.

32 Wong A, Allman-Farinelli M, Erickson B, et al: Randomised controlled trial to determine the efficacy of prescribed fluid intake to reduce progression in ADPKD (PREVENTADPKD). Nephrol (Carlton) 2016;21(suppl 2):150-280.

33 Campbell KL, Rangan GK, Lopez-Vargas P, Tong A: KHA-CARI autosomal dominant polycystic kidney disease guideline: diet and lifestyle management. Semin Nephrol 2015; 35:572-581.e17.

34 van Gastel MD, Meijer E, Scheven LE, Struck J, Bakker SJ, Gansevoort RT: Modifiable factors associated with copeptin concentration: a general population cohort. Am J Kidney Dis 2015;65:719-727.

35 Torres VE, Grantham JJ, Chapman AB, et al: Potentially modifiable factors affecting the progression of autosomal dominant polycystic kidney disease. Clin J Am Soc Nephrol 2011;6:640-647.
36 Torres VE, Abebe KZ, Schrier RW, et al: Dietary salt restriction is beneficial to the management of autosomal dominant polycystic kidney disease. Kidney Int 2017;91:493-500.

37 Bankir L, Roussel R, Bouby N: Protein- and diabetes-induced glomerular hyperfiltration: role of glucagon, vasopressin, and urea. Am J Physiol Renal Physiol 2015;309:F2-F23.

38 Amro OW, Paulus JK, Noubary F, Perrone $\mathrm{RD}$ : Low-osmolar diet and adjusted water intake for vasopressin reduction in autosomal dominant polycystic kidney disease: a pilot randomized controlled trial. Am J Kidney Dis 2016;68:882-891.

39 Vendramini LC, Nishiura JL, Baxmann AC, Heilberg IP: Caffeine intake by patients with autosomal dominant polycystic kidney disease. Braz J Med Biol Res 2012;45:834-840.

40 Ozkok A, Akpinar TS, Tufan F, et al: Clinical characteristics and predictors of progression of chronic kidney disease in autosomal dominant polycystic kidney disease: a single center experience. Clin Exp Nephrol 2013;17:345351

41 Orth SR, Stockmann A, Conradt C, et al: Smoking as a risk factor for end-stage renal failure in men with primary renal disease. Kidney Int 1998;54:926-931.

42 Veloso Sousa M, Godoy Amaral A, Balbo BE Souza Messias F, de Castro I, Onuchic LF: Smoking worsens the renal phenotype of PKD1-deficient cystic mice. J Am Soc Nephrol 2016;27:771A.

43 Enhorning S, Bankir L, Bouby N, et al: Copeptin, a marker of vasopressin, in abdominal obesity, diabetes and microalbuminuria: the prospective Malmö diet and cancer study cardiovascular cohort. Int J Obes (Lond) 2013; 37:598-603.

44 Pietrzak-Nowacka M, Safranow K, Byra E, Binczak-Kuleta A, Ciechanowicz A, Ciechanowski K: Metabolic syndrome components in patients with autosomal-dominant polycystic kidney disease. Kidney Blood Press Res 2009;32:405-410. 